\title{
Consumer Innovation Management in the Mining Industry Economy
}

\author{
Naylya Amirova ${ }^{1}$, Lyudmila Sargina ${ }^{1}$, and Asiya Khasanova $^{1}$ \\ ${ }^{1}$ Plekhanov Russian University of Economics, Academic Departments of Political Economy and of \\ the History of Economic Science, 117997, Moscow, 36 Stremyanny lane, Russia
}

\begin{abstract}
The development of product innovations acts as the directions of influence on consumer choice in the market for innovative products of mining region. Using the consumer as a generator of ideas and initiator of a new innovation process can significantly reduce the level of uncertainty and risk, as well as increase the efficiency of innovative projects in the mining industry. Currently, consumer-oriented business creates special processes, namely marketing and sales. A similar process should be initiated in the commodity sector. In the extractive industry, Customer Relationship Management (CRM) tools must be used to produce raw materials as the goods targeted at future customers. With regard to mining sector, this strategy should be based on the principles of a systematic approach, longterm partnership, the use of information and communication technologies, as well as the involvement of all owners of mining enterprise's business processes in the communication system with the participation of the consumer.
\end{abstract}

\section{Introduction}

Recognition of consumers of innovative products as significant participants in the innovation process led to an understanding of the need to search for tools for managing their behavior, which are considered as management tools focused on the future consumer. Traditionally, the development of product innovations based on taking into account changes in the system of preferences and expectations of consumers, as well as expanding the product range based on market segmentation, identifying the volume and characteristics of demand in each segment, have acted as directions of influencing consumer choice in the market for innovative products. At the same time, in the system of innovation management, the potential of feedback from consumers is not properly used. As the consequence, during processing of raw materials new ideas about the content of product innovations can appear that differ in the level of radicality (basic, systemic, developmental, pseudo-innovations).

\section{Materials and Methods}

Using the consumer as a generator of ideas and initiator of innovation process can significantly reduce the level of uncertainty and risk with which it is associated, and also increases the efficiency of innovative projects. This is due to the fact that the product innovation allows the customer to fully realize its preferences, while fundamental and applied 
scientific research that initiates the innovation process acts as a non-price factor of the supply that does not fully reflect the permanent changes in consumer preferences. Thus, the risk of lack of demand for innovative products remains, which hinders the commercialization of innovations. In the context of a deteriorating macroeconomic environment and a decrease in raw materials comsumption during COVID-19, taking into account consumer preferences is a tool to stimulate demand in the market for innovative basic stuff.

In our article, we rely on the theories of F. Crawford and R. Mathews, who interpreted the modern consumer as "instavidual" (a neologism formed from the words instant and individual, i.e. the needs of "instaviduals" are constantly changing, while the tendency of individualization of consumption is realized [1].

The formation of the consumer market, as well as the deterioration of the situation in the main markets for raw materials, led to the need to develop a management system focused on customers and maintaining their loyalty. Customer-oriented management, as a tool to increase the competitive potential of an enterprise, is used by a number of successful enterprises in the Russian Federation and abroad. Nevertheless its tools, along with consumer innovations as an object of management, have not been adequately studied. Traditionally, the intellectual and creative resource of an enterprise is considered as a generator of innovative ideas, which, in particular, is reflected in the theory of intra-firm entrepreneurship, the theory of an innovative economy and a knowledge-based economy in conjunction with the technology of entrepreneurial management, etc. Recognition of the consumer as a generator and (or) the developer of innovative ideas (E. von Hippel) [2] does not entail an analysis of the tools used in management.

The category "consumer innovation" does not have a unified interpretation in the theory of innovation management. Within the framework of the communicative concept of marketing, consumer innovation is a kind that reflects the communication functions performed by various elements of the marketing mix that are novel for the consumer. According to this interpretation, consumer innovation is considered as a brand presentation tool, and on the other hand acts as a communicative tool that can affect various cognitive and mental processes of the consumer.

The corporate consumer is guided by a different composition of motives in the production of consumer innovation, namely: reference to the analysis of consumer preferences as a source of innovative ideas and tools to reduce the market risks of product, as well as in order to reduce the time for the implementation of the pre-project stage and increasing consumer loyalty, obtaining reliable information about the composition of the preferences. Thus, the prerequisites are formed for the transformation of absolute and relative advantages into sustainable competitive advantages of the enterprise. In other words, the manufacturer and the consumer are interested in the formation of consumer innovations, which determines the possibilities of their cooperation, and also determines the need to develop tools and management technologies adapted to this type of innovation.

It can be argued that there are difference between the types of innovation process depending on the essence of the selected innovations - consumer or traditional. Taking this difference into account makes it possible to justify management tools adapted to the type of innovation. Tab. 1 shows the stages of the innovation process focused on future consumers. 
Table 1. Stages of the innovation process focused on future consumers.

\begin{tabular}{|c|c|}
\hline Stages of the innovation process & $\begin{array}{l}\text { The content of the innovation, the subject } \\
\text { composition of the participants in the } \\
\text { innovation process }\end{array}$ \\
\hline $\begin{array}{c}\text { The stage of strategic analysis and development } \\
\text { of an innovation-oriented mining company } \\
\text { development strategy }\end{array}$ & $\begin{array}{l}\text { The mining company conducts a strategic } \\
\text { analysis of the external environment of the } \\
\text { enterprise, segmentation of the market, taking } \\
\text { into account the subject composition of } \\
\text { consumers, develops an innovation-oriented } \\
\text { strategy for its development, which is aimed } \\
\text { at adaptation to changing environmental } \\
\text { factors or ensures their transformation in } \\
\text { accordance with the target guidelines of the } \\
\text { subject of innovation; a preliminary analysis } \\
\text { of the innovation project is carried out in } \\
\text { order to determine its competitiveness }\end{array}$ \\
\hline $\begin{array}{l}\text { The stage of the birth of a new idea as a result of } \\
\text { fundamental and applied scientific research }\end{array}$ & $\begin{array}{l}\text { An innovative idea is the result of the } \\
\text { implementation of intra-firm } \\
\text { entrepreneurship, the subject of which } \\
\text { simultaneously acts as a consumer of a } \\
\text { product or service innovation }\end{array}$ \\
\hline $\begin{array}{l}\text { The stage of development work, design } \\
\text { developments, which are embodied in a prototype }\end{array}$ & $\begin{array}{l}\text { The consumer initiates ideas aimed at } \\
\text { improving (developing) the consumed goods }\end{array}$ \\
\hline Sampling stage & $\begin{array}{l}\text { The consumer, along with the manufacturer, } \\
\text { participates in the selection of a sample } \\
\text { intended for replication }\end{array}$ \\
\hline $\begin{array}{c}\text { The stage of financial and economic justification } \\
\text { for the product }\end{array}$ & $\begin{array}{l}\text { Consumer behavior (the volume of consumer } \\
\text { spending, non-price factors of demand, etc.) } \\
\text { is taken into account in the course of the } \\
\text { financial and economic justification for the } \\
\text { production of innovation }\end{array}$ \\
\hline Primary development stage & $\begin{array}{l}\text { Formation of distribution (sales) channels } \\
\text { taking into account consumer preferences }\end{array}$ \\
\hline $\begin{array}{l}\text { Diffusion stage of innovation, or its } \\
\text { commercialization }\end{array}$ & $\begin{array}{l}\text { Innovation to create and expand the } \\
\text { boundaries of an existing brand in response to } \\
\text { changing needs }\end{array}$ \\
\hline $\begin{array}{l}\text { The stage of dominance of innovation in the local } \\
\text { market or field of activity, the transformation of } \\
\text { innovation into a tradition }\end{array}$ & $\begin{array}{l}\text { Development of innovations and pseudo- } \\
\text { innovations, taking into account changing } \\
\text { needs in order to extend the innovation life } \\
\text { cycle }\end{array}$ \\
\hline $\begin{array}{l}\text { The stage of substitution of innovation, which } \\
\text { may coincide with the stage of the birth of a new } \\
\text { idea }\end{array}$ & $\begin{array}{l}\text { Development of niche innovations adapted to } \\
\text { the peculiarities of submarkets, taking into } \\
\text { account the behavior of their participants }\end{array}$ \\
\hline
\end{tabular}

The study of the features of the innovation process initiated by the consumer allows us to conclude that it is characterized by a number of features that distinguish it from the cycle of traditional innovations. These include the fact that the efficiency of the innovation process and the volume of externalities are determined by the intensity of communications between the consumer and the manufacturer. At the same time, the results of all stages of the innovation process depend on this factor. In addition, the risks of developing and implementing innovative projects associated with the perception of innovation by the 
consumer are reduced. It includes the risks of erroneous planning, calculation and estimates (due to market segmentation and taking into account consumer preferences); risks of originality (as a result of the initiation of an innovative idea by the consumer); risk of unmanageability of the project (combination of originality and sophistication of the project and the cohesion and professionalism of the management team).

\section{Results and Discussion}

In the period from the 1990 s to date, in mining industry a customer-oriented approach to the innovation management system is dominating, the key participants of which are partners and consumers, along with marketers, scientists, researchers, top managers who focus on the future consumer, use customer relationship management systems (CRM- system), implement the strategy of product customization and brand strategy. Selection of innovative projects using the method of joint participation of stakeholders - consumer and manufacturer. The main asset of the company is communication with the participation of consumers.

The key principles of a customer-oriented approach include [4]:

1. Focus on loyal customers, which avoids the cost of attracting new customers. Individual communications with clients. Reducing the importance of traditional tools for dealing with competitors.

2. Collaboration with customers based on relationship, not product. At the same time, consumers view the company as the bearer of some idea that is of particular value to them.

3. Mass customization, or a modular approach to the production of goods and services, providing a comprehensive account of individual needs.

An obstacle to the development and implementation of a customer-oriented strategy in mining enterprises is the high costs of its implementation, associated with the need to change the composition of the key factors of the manufacturer's success, as well as the lack of formalized methods of interaction with customers.

The long payback period for innovations, limited access to debt financing, and low efficiency of tax incentives are significant factors that hinder the implementation of a clientoriented approach by Russian mining companies. The factors of the internal environment that limit the implementation of a client-oriented approach include a shortage of personnel and innovation managers, and the founders' lack of interest in the innovation model. At the same time, the problem of a long payback period for innovations does not have clear, easily interpretable determinants. There is a sectoral specificity of the activities of mining enterprises, which consists in limited access to financing [5].

The advantages of using consumer innovations within the framework of a client-oriented approach are short-term effects, which are expressed in shortening the pre-project stage and reducing the level of risk of perception of innovations by consumers during the implementation of an innovative project, as well as long-term effects, consisting in increasing the level of customer loyalty and improving financial and economic performance of mining enterprise [6].

The introduction of CRM technologies necessitates the development of criteria for assessing the effectiveness of enterprises, reflecting the completeness of the implementation of a client-oriented strategy. Nraditional indicators of enterprise performance (sales, profit, cash flow) should be supplemented with indicators of loyalty and stability of the customer base, customer satisfaction, the proportion of sales and profit received as a result of attracting new customers [8].

A study of the activities of a number of Russian mining enterprises has shown that the most difficult task is the formation of a customer-oriented organizational culture, which implies the implantation of certain behavioral models of the enterprise employees, suggesting that the latter are focused on studying the changing needs of customers and creating 
conditions for their maximum satisfaction. In this regard, there is a need to formalize the communication system with consumers, to train and motivate personnel, to organize a workspace in order to involve consumers in the process of developing, customizing and selling innovative products.

Regardless of the type of organizational structure of a mining enterprise, the orientation of all its departments to the client ensures their integration, coordination within the network or information types of the innovation process.

Management technologies in relation to the personnel of a customer-oriented enterprise include marketing automation, sales automation, service automation, creation of a bank of ideas. Management technologies in relation to consumers of the products of a customeroriented enterprise include Internet marketing, electronic sales and storefronts, self-service, interactive communications. The use of such technologies contributes to the formation of partner marketing, partner sales and services, and also ensures the development and implementation of consumer innovations and customer-oriented technologies.

Taken together, these divisions provide the formation of a data bank on consumer choice and factors, the use of which in the innovation process ensures its transformation into an innovative CRM. At the same time, communicative CRM is focused on improving interactions with customers, analytical CRM allows you to generalize and systematize the customer base, which is a necessary prerequisite for developing forecasts and creating a bank of consumer ideas.

It should be borne in mind that at the same time there are factors that impede the formation of a future-oriented management system. The system-wide factors contributing to the introduction of a customer-oriented management system, include: the deterioration of the macroeconomic environment and the search for tools, the use of which can promote consumer spending as a component of total spending; intensification of competition amid falling demand; development of Western and Russian experience in the application of customer-oriented management, expansion of the scope of application of the case-study method as a modern technology of professionally oriented education.

At the same time, among the backbone factors, one should single out those that create obstacles to the implementation of the studied management system at a mining enterprise, namely: orientation of producers to short-term goals; high level of industry monopolization; personalization of communications with the participation of customers, which does not allow using the potential of the latter for the development of the competitive advantages of the enterprise.

The management factors contributing to the implementation of the principles of customer-centered management include:

- the presence of an agency contradiction, which can be overcome on the basis of the introduction of CRM technologies;

- a high level of uncertainty in the external environment, adaptation to which implies the need to develop and implement entrepreneurial strategies aimed at changing it in accordance with the target guidelines for the development of the enterprise;

- the use of ERP solutions, which created the objective prerequisites for the formation of CRM systems [9].

At the same time, the focus on short-term goals in making managerial decisions, lack of experience in marketing management and individual marketing, low adaptation of the management systems prevailing in developed countries to Russian reality and the lack of internal concepts of interaction with clients at the enterprise, supported by practical methods, creates obstacles for implementation of CRM technologies.

The high level of digitalization of society predetermined the possibility of widespread use of ICT as a tool for the implementation of CRM technologies [10]. At the same time, the unevenness of informatization of the economic space and high polarization limit the 
possibilities of using CRM technologies. Finally, the development of methodological approaches to assessing the effectiveness of modern management technologies and algorithms for their implementation, taking into account Russian reality, contribute to the use of CRM systems. At the same time, the implementation of customer-oriented management is hampered by the insufficient level of professional and general cultural competencies of managers and owners of enterprises, which hinders the reengineering of business processes, as well as a low culture of intercorporate relations.

\section{Conclusion}

Thus, CRM technologies are a necessary tool for implementing the entrepreneurial strategy of a mining enterprise, which is focused on transforming environmental factors in accordance with the strategic goals and objectives of a business entity. At the same time, one should take into account the need of customers to share innovative ideas with companies free of charge, which is a form of realizing the need for their own potential (self-affirmation) and belonging to a certain social group - competent specialists. Thus, the innovation process, which results in consumer innovation, includes the stage of direct receipt of consumer ideas and marketing (the initial stage of the innovation project - intellectual production), the stage of development and material production, the stage of diffusion and consumption.

\section{References}

1. F. Crawford, R. Mathews, The Myth of Excellence: Why Companies Never Try to Be the Best at Everything (Crown Business, New York, 2001)

2. E. von Hippel, G. von Krogh, Organization Science 14, 209-223 (2003)

3. R. Rothwell, International Marketing Review 11(1), 7-31 (1994)

4. S. Hokanson, Marketing News 29(1), 16 (1995)

5. E. Yu. Dotsenko, N.P. Ezdina, S.V. Mudrova, E3S Web of Conferences 41, 04050 (2018)

6. N. Amirova, L. Sargina, A. Khasanova, E3S Web of Conferences 174, 02011 (2020)

7. V.V. Shlychkov, A.S. Khasanova, I.K. Kiyamov, S.M. Kulish, D.R. Nestulaeva, European Research Studies Journal 20(2B), 200-223 (2017)

8. A.Sh. Khasanova, M.P. Postaluk, Academy of Strategic Management Journal 15(S2), 1 (2016)

9. H. Anderson, P.F. Jacobsen, Creating Loyalty: Its Strategic Importance in Your Customer Strategy (John Wiley, Ontario, 2000)

10. E. von Hippel, The Economist 10, 1 (2005) 